\title{
EKSISTENSI SURAU DI ERA MODERNISASI: DAYA TAHAN DAN PERUBAHAN SURAU BUYA LUBUAK LANDUA DI PASAMAN BARAT
}

\author{
Miftahul Khoiroti \\ Institut Agama Islam Negeri (IAIN) Bukittinggi, miftahulkhoiroti70@gmail.com

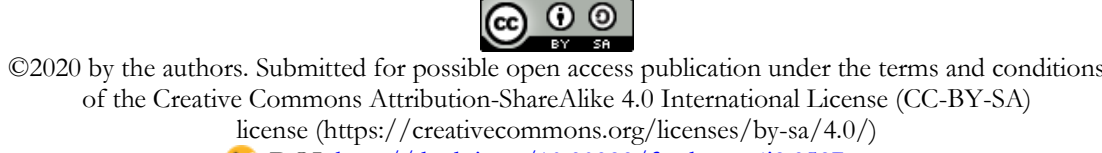

Diterbitkan: 31 Desember 2020

\begin{abstract}
This research examines the resilience and change of Surau Buya Lubuak Landua in the West Pasaman region, which is 167 years old in the midst of modernization. Although in his journey Surau Buya Lubuak Landua has experienced a crisis due to ideas of religious reform in all its aspects which caused the suran to experience shock, nevertheless Surau Buy L Lubuak Landua has survived until now. This research uses a qualitative-descriptive method. This method tries to explain all events, incidents related to Suran Buya Lubuak Landau in detail according to current conditions. The results showed that the existence of Suran Buya Lubuak Landua had a very significant development, with an estimated age that was as old as Islam in the West Pasaman region. During its development, Surau was more focused on teaching religious education. The development and durability of the Buya Lubuak Landua surau was possible because of the comprehensive cooperation between Buya Lubuak Landua, the government, traditional leaders, and the community in maintaining the sustainability of the surau. In addition, Buya Lubuak Landua's ability to streamline the elements of surau to function properly can help mobilize the economic potential of the Lubuak. Landua community.
\end{abstract}

Keywords: Surau; Modernization; West Pasaman.

\begin{abstract}
Abstrak
Penelitian ini mengkaji daya tahan dan perubahan Surau Buya Lubuak Landua di wilayah Pasaman Barat yang telah berusia 167 tahun di tengah arus modernisasi. Meskipun dalam perjalanannya Surau Buya Lubuak Landua pernah mengalami krisis akibat adanya ide-ide pembaharuan keagamaan dalam segenap aspeknya yang menyebabkan surau mengalami goncangan, namun demikian Surau Buya Lubuak Landua tetap bertahan hingga saat ini. Penelitian ini menggunakan metode kualitatif-deskriptif. Metode ini berusaha menjelaskan segala peristiwa, kejadian yang berhubungan dengan Surau Buya Lubuak Landau secara terperinci sesuai dengan kondisi sekarang. Hasil penelitian menunjukkan bahwa eksistensi Surau Buya Lubuak Landua mengalami perkembangan yang sangat signifikan, dengan capaian usia yang diperkirakan setua usia Islam di wilayah Pasaman Barat. Dalam perkembangannya, surau lebih terfokus pada pengajaran pendidikan agama. Perkembangan dan daya tahan surau Buya Lubuak Landua dapat terlaksana karena adanya kerjasama yang komprehensif antara Buya Lubuak Landua, pemerintah, pemuka adat, dan masyarakat dalam menjaga keberlangsungan surau. Selain itu kemampuan Buya Lubuak Landua dalam mengefektifkan unsur-unsur surau agar berfungsi dengan baik dapat membantu dalam menggerakkan potensi ekonomi masyarakat Lubuak Landua.
\end{abstract}

Kata Kunci: Surau, Modernisasi, Lubuak Landua, Pasaman Barat. 


\section{PENDAHULUAN}

Modernisasi telah merambah di berbagai bidang kehidupan manusia. Modernisasi akan berimplikasi pada perubahan tatanan sosial masyarakat karena dibarengi dengan masuknya budaya dari luar. Ketika budaya luar unsurunsurnya lebih maju, berwatak kapitalis, dihadapkan dengan budaya lokal yang berwatak tradisional, terjadi pergulatan antara budaya luar dengan budaya lokal. Pertarungan kedua budaya tersebut akan memberikan dampak bagi masyarakat, unsur yang tersisih akhirnya tidak berfungsi dan digantikan oleh unsur baru yang kemungkinan besar dimenangkan oleh budaya luar. Biasanya, unsur lokal berangsur-angsur menurun dan tidak lagi diminati oleh masyarakat tradisional. ${ }^{1}$ Salah satu contohnya adalah institusi surau.

Surau adalah salah satu institusi yang berperan penting dalam pengembangan nilai- nilai moral agama dan juga adat istiadat Minangkabau. Dari suraulah cikal bakal pertumbuhan dan keutamaan masyarakat minangkabau yang bermartabat dan beragama di jalankan secara bersama. Keberhasilan dalam proses pendidikan anak-anak Minangkabau ditandai dengan pandai mengaji, taat beribadah, berakhlak dan berkepribadian luhur. Mampu memakai tata krama adat, pandai petatah petitih adat, danmenguasai kesenian anak nagari serta bela diri (silat). ${ }^{2}$

Falsafah adat basandi syara', syara' basandi Kitabullah, syara' mangato adat mamakai dapat kita lihat dari kehidupan surau. Pada masa sekarang ini

'Sholeh Suaidi, "Islam Dan Modernisme," Islamuna: Jurnal Studi Islam 1, no. 1 (January 4, 2014): 49-61, http://ejournal.stainpamekasan.ac.id/index.php/islamuna/ article/view/558.

${ }^{2}$ Azyumardi Azra, Surau: Pendidikan Islam Tradisionalis Dalam Transisi Dan Modernisasi Jakarta: Kencana, 2017); Mas'ud Zein, "Sistem Pendidikan Surau: Karakteristik, Isi Dan Literatur Keagamaan," Sosial Budaya 8, no. 1 (2011): 25-39; Darwianis, “Tindak Lanjut Kebijakan Kembali Ke Nagari Dan Ke Surau Serta Dampaknya Terhadap Kehidupan Sosial Adat Keagamaan Masyarakat," Jurnal PPKn \& Hukum 12, no. 22 (2017): 83101. peranan surau tidaklah sepenting yang dulu lagi, hal ini dikarenakan perkembangan zaman dan era globalisasi. Modernisasi sistem pendidikan mempunyai kecendrungan ke arah sekularisasi. Kecendrungan ini merupakan monumental yang terjadi dalam suatu sistem pendidikan tanpa disadari perubahan tersebut telah menindih kearifan-kearifan lokal yang ada dalam sistem pendidikan lama. ${ }^{3}$

Pada akhirnya pengaruh modernisasi ini melahirkan kaum intelektual yang modernisrasionalis. Kaum intelektual ini memerankan peran penting dalam berbagai bidang kehidupan, kondisi tersebut mempengaruhi pola piker masyarakat Minangkabau sehingga sekolahsekolah modern cepat diakses dan dijadikan sebagai institusi pilihan.

Sementara itu pembinaan surau yang tidak efektif semakin memperlemah eksistensi surau ditengah-tengah sistem pendidikan modern tersebut yang kemudian peranan surau sebagai tempat pendidikan non formal di Minangkabau mulai ditinggalkan dan tidak lagi diminati oleh anak nagari. ${ }^{4}$ Banyak surau yang beralih fungsi akibat dari modernisasi. Berbeda dengan Surau Buya Lubuak Landua.

Surau Buya Lubuak Landua di bangun oleh Syekh Muhammad Basyir pada tahun 1852. Muhammad Basyir adalah seorang ulama yang berasal dari Pasaman Barat. Muhammad Basyir tumbuh dalam keluarga yang taat beribadah, berfikiran terbuka dan kritis. Pada tahun 1835 M, Syekh Muhammad Basyir menuntut ilmu ke Kumpulan. Kumpulan adalah salah satu nama

${ }^{3}$ Muhammad Mawangir, "Modernization Of Islamic 'Surau' Traditional Education In West Sumatera, Indonesia," Journal of Islamic Studies and Culture 3, no. 2 (2015), http://jiscnet.com/vol-3-no-2-december-2015abstract-4-jisc; Pramono Pramono, "Surau Dan Tradisi Penaskahan Islam Di Minangkabau, Studi Atas Dinamika Tradisi Pernaskahan Di Surau-Surau Di Padang Dan Padang Pariaman," HUNAFA: Jurnal Studia Islamika 6, no. 3 (December 15, 2009): 247, http://jurnalhunafa.org/index.php/hunafa/article/view/13 7.

${ }^{4}$ Silfia Hanani, Surau: Aset Lokal Yang Tercecer (Bandung: Humaniora Utama Press, 2002), 104. 
daerah yang terletak di Kabupaten Pasaman Timur.

Pada masa itu, daerah Kumpulan merupakan daerah yang terkenal sebagai tempat untuk belajar ilmu tasawuf Naqsyabandiyah. Karena adanya Syekh yang terkenal disana bernama Maulana Syekh Ibrahim Bin Fahati alKhalidi Kumpulan. Selama tahun (1764-1914) Muhammad Basyir mengabdikan diri di Kumpulan.

Karena ketaatan dalam menuntut ilmu, Muhammad Basyir kemudian diberi gelar Maulana oleh Syekh Ibrahim. Seolah belum merasa cukup dengan pendidikan yang diperoleh dari Kumpulan, Muhammad Basyir kemudian berencana melanjutkan pendidikannya ketingkat yang lebih tinggi lagi. Ketertarikan dan rasa tidak puas inilah yang kemudian membuat Syekh Muhammad Basyir memutuskan untuk memperdalam ajaran agama Islam ke Mekkah alMukarramah.

Di samping untuk menunaikan ibadah haji, Syekh Basyir berusaha meluangkan waktu untuk menuntut ilmu ke berbagai ulama-ulama yang ada disana. Salah satu ilmu yang sangat didalami oleh Syekh Muhammad Basyir adalah Tarekat Naqsyabandiyah. Meskipun sebelumnya beliau telah mempelajarinya di Kumpulan. Karna ketekunan dalam belajar, khususnya dalam bidang Tarikat Naqsyabandiyah, Syekh Basyir kemudian memperoleh ijazah Naqsyabandiyah dari Syekh Ali Ridha di Jabal Abi Qurais Mekkah. ${ }^{5}$

Setelah menyelesaikan pendidikan di Mekkah al-Mukarramah, Syekh Muhammad Basyir kemudian pulang ke kampung halamannya. Dari Kampung halamannya beliau kemudian memilih daerah Lubuak Landua sebagai tempat untuk memapankan karir keulamaannya.

Lubuak Landua adalah salah satu Nagari dari Kecamatan Pasaman yang terletak di Kabupaten Pasaman Barat, Sumatera Barat. Berjarak $10 \mathrm{~km}$ dari kota Simpang Empat atau Mei 2019. empat jam perjalanan dari kota padang. Lubuak Landua merupakan daerah yang berhawa sejuk karena memiliki ketinggian $300 \mathrm{~m}$ di atas permukaan laut. Selain itu Lubuak Landua juga dikaruniai sumber air yang melimpah. Lokasi inilah yang dijadikan sebagai tempat untuk membangun surau oleh Syekh Muhammad Basyir. Surau dibangun tepat di tepi pinggiran sungai.

Surau ini kemudian dijadikan Syekh Muhammad Basyir sebagai tempat untuk mengajarkan pendidikan agama Islam. Keinginan dalam membangun surau ini dilatar belakangi oleh pengamatan akan kurangnya pemahaman masyarakat Pasaman Barat dalam memahami ajaran agama Islam pada masa itu. ${ }^{6}$

Islam sebagai agama rahmatallil'alamin hendaknya dipelajari dengan sungguh- sungguh. Ditambah lagi dengan ajaran Islam yang aspeknya mempelajari seluruh tatanan kehidupan, perlu di jelaskan secara perlahan serta membutuhkan waktu yang lama. Karna hal inilah Syekh Muhammad Basyir berfikir tentang perlu adanya wadah atau lembaga khusus dalam mengenalkan agama Islam.

Tanpa melalui pendidikan agama Islam akan sulit dijelaskan kepada masyarakat Pasaman Barat. Maka dibangunlah oleh Syekh Basyir sebuah surau. Surau inilah yang kemudian dinamai dengan Surau Buya Lubuak Landua.

Meskipun dalam perjalanannya, eksistensi Surau Buya Lubuak Landua pernah mengalami krisis akibat adanya ide-ide pembaharuan keagamaan dalam segenap aspeknya yang menyebabkan surau mengalami goncangan. Akan tetapi, meskipun demikian nyatanya Surau Buya Lubuak Landua tetap bertahan hingga saat ini. Eksistensi, dan daya tahan surau Buya Lubuak Landua terhadap perubahan menarik untuk dikaji. Selain itu, sejarah surau, serta sistem pendidikan Surau Buya Lubuak Landua juga patut dipahami oleh generasi saat ini, sehingga

${ }^{6}$ Mustafa Kamal (Regenerasi Buya Lubuak Landua ke VI), Wawancara, 24 April 2018. 
nilai-nilai pendidikannya dapat diaktualisasikan dalam konteks kekinian.

Penelitian ini menggunakan pendekatan kualitatif deskriptif. Pendekatan kualitatif deskriptif adalah metode yang berusaha mendeskripsikan peristiwa dan kejadian yang terjadi saat sekarang. Konsep metode ini mengarahkan formatnya pada keaslian data, dan kealamian. Teknik pengumpulan data dilakukan dengan teknik observasi dan wawancara. ${ }^{7}$

Ananlisis data menggunakan model sebagaimana dikemukakan oleh Miles dan Hubermiles, terdiri dari pengumpulan data, reduksi data, penyajian data dan penarikan kesimpulan. $^{8} \quad$ Subjek penelitian ini adalah regenerasi Buya Lubuak Landua yang ke VI, dan pengurus Surau Buya Lubuak Landua selaku informan kunci (key informan). Sedangkan pemuka adat atau kepala Jorong Nagari Persiapan Lubuak Landua, masyarakat asli yang tinggal di lokasi sekitaran Surau Buya Lubuak Landua dan jamaah Surau Buya Lubuak Landua dijadikan sebagai informan pendukung.

\section{SURAU DAN MODERNISASI}

Istilah surau, kadang-kadang dibaca suro, adalah kata yang luas penggunaannya di Asia Tenggara. Sejak dulu, istilah ini telah digunakan secara meluas di Minangkabau, Tanah Batak, Sumatera Tengah, Sumatera Selatan, Semenanjung Malaya dan Patani (Thailand Selatan) dalam arti yang sama. Secara linguistik, kata surau berarti "tempat" atau "tempat penyembahan".

Menurut pengertian asalnya, surau adalah sebuah bangunan kecil yang aslinya dibangun untuk penyembahan nenek moyang. Karena alasan ini, surau paling awal biasanya didirikan di

${ }^{7}$ Sunyoto Usman, Sosiologi: Sejarah, Teori Dan Metodologi (Yogyakarta: CIReD, 2004); Nyoman Kutha Ratna, Metodologi Penelitian: Kajian Budaya Dan Ilmu Sosial Humainiora Pada Umumnya No Title (Yogyakarta: Pustaka Pelajar, 2010).

${ }^{8}$ Mathew B.dan Huberman Miles and A Michael, Anaalisis Data Kualitatif: Buku Sumber Tentang Metode-Metode Baru, Terj. Tjetjep Rohendi Rohidi (Jakarta: UI-Press, n.d.). puncak bukit atau tempat yang lebih tinggi dari lingkungannya. Juga sangat mungkin, bahwa surau berkaitan erat dengan pedesaan, meskipun dalam perkembangannya kemudian surau juga dapat ditemukan di daerah urban. ${ }^{9}$

Di Minangkabau, bahkan sebelum kedatangan Islam, surau telah mempunyai kedudukan penting dalam struktur masyarakat. Fungsinya lebih dari sekedar tempat kegiataan keagamaan. Menurut ketentuan adat, surau berfungsi sebagai tempat berkumpulnya para remaja laki-laki dewasa yang belum kawin atau duda. Karena adat menentukan bahwa laki-laki tidak punya kamar di rumah orangtua nya, karena itu mereka bermalam di surau. Kenyataan ini menyebabkan surau menjadi tempat amat penting bagi pendewasaan generasi muda Minangkabau, baik dari segi ilmu pengetahuan maupun keterampilan praktis lainnya. ${ }^{10}$

Dengan datangnya Islam, surau kemudian mengalami proses Islamisasi, tanpa harus mengalami perubahan nama. Di beberapa wilayah, bekas surau Hindu-Buddha, terutama yang terletak di daerah terpencil seperti puncak bukit, hilang dengan cepat karena pengaruh Islam. Karena itu, surau Islam biasanya dapat ditemukan dekat kawasan pemukiman kaum muslimin. Tetapi, sisa-sisa kesakralan surau pra-Islam dalam beberapa kasus masih dapat dilihat, misalnya di daerah Minangkabau banyak surau memiliki beberapa puncak atau gonjong, yang selain merefleksikan kepercayaan mistis tertentu, juga dipandang sebagai simbol adat. ${ }^{11}$

Di sini tampak jelas bahwa Islam juga mengalami akulturasi budaya. Terlepas dari bentuk

${ }^{9}$ Azra, Surau: Pendidikan Islam Tradisionalis Dalam Transisi Dan Modernisasi.

${ }^{10}$ Melia Afdayeni, "Dinamika Sistem Pendidikan Islam (Surau) Minangkabau Pradan Pasca Pemabaharuan," Jurnal Fuaduna: Jurnal Kajian Keagamaan dan Kemasyarakatan 1, no. 1 (2017): 58-69.

${ }^{11}$ Alfurqan Alfurqan, "Evolution and Modernization of Islamic Education In Minangkabau," Afkaruna 16, no. 1 (2020), https://journal.umy.ac.id/index.php/afkaruna/article/view $/ 7951$. 
arsitekturnya, surau menjadi bangunan keislaman. Istilah surau kemudian mengacu kepada suatu "mesjid kecil", yang biasanya tidak digunakan untuk Shalat Jum'at. Surau bukanlah masjid dalam pengertian umum, meskipun ia juga digunakan untuk berbagai kegiatan keagamaan. ${ }^{12}$

Berbeda dengan bentuk surau di Minangkabau yang memiliki beberapa puncak dan gonjong, bentuk Surau Buya Lubuak Landua lebih kepada bentuk rumah panggung yang konstruksi bangunannya terbuat dari kayu. Bentuk bangunan Surau Buya Lubuak Landua lebih mirip seperti rumah zaman dulu. Tidak banyak yang berubah dari konstruksi bangun surau, surau mengalami perluasan wilayah karena semakin lama jumlah jamaah Surau Buya Lubuak Landua semakin bertambah. Selain itu, Surau Buya Lubuak Landua mengalami perubahan karena adanya bagianbagian di dalam surau yang perlu diganti, seperti kayu yang mulai rapuh serta atap surau yang mulai rusak karna termakan usia.

Adapun istilah modern sering kali "dilawankan" dengan istilah tradisional. Arti kata modernisasi dengan kata dasar modern berasal dari bahasa Latin“modernus"yang dibentuk dari kata modo dan ernus. Modo berarti cara dan ernus merujuk pada adanya periode waktu masa kini. Modernisasi berarti proses menuju masa kini atau proses menuju masyarakat yang modern. Modernisasi dapat pula berarti perubahan dari masyarakat tradisional menuju masyarakat yang modern. ${ }^{13}$

Adapun syarat-syarat suatu modernisasi menurut Soerjono Soekanto adalah sebagai berikut:

1. Cara yang berfikir ilmiah (scientific binking) yang institutionalized dalam the ruling class maupun masyarakat. Hal ini menghendaki

${ }^{12}$ Meimunah S Moenada, "Surau Dan Modernisasi Pendidikan Di Masa Hindia Belanda," Sosial Budaya 8, no. 1 (2011): 40-54.

${ }^{13}$ Kamanto Sunarto, Sosiologi Perubahan Sosial (Jakarta: Rajawali Press, 2012), 80-81. suatu sistem pendidikan dan pengajaran yang terencana dan baik.

2. Sistem administrasi Negara yang baik, yang benar-benar mewujudkan birokrasi.

3. Adanya sistem pengumpulan data yang baik dan teratur yang terpusat pada suatu lembaga atau badan tertentu. Hal ini memerlukan penelitian yang kontiniu, agar data termaksud tidak tingggal.

4. Penciptaan iklim yang favourable dari masyarakat terhadap modernisasi dengan cara penggunaan alat-alat komunikasi masa. Hal ini harus dilakukan tahap demi tahap karena banyak sangkut pautnya dengan sistem kepercayaan masyarakat.

5. Tingkat organisasi yang tinggi, yang disatu pihak berarti disiplin, sedangkan dilain pihak berarti pengurangan kemerdekaan.

6. Sentralisasi wewenang dalam pelaksanaan social planning.

Apabila hal itu tidak dilakukan, maka perencanaan akan terpengaruh oleh kekuatankekuatan dari kepentingan-kepentingan yang ingin mengubah perencanaan tersebut demi suatu kepentingan suatu golongan kecil dalam masyarakat.

Cyril Black, yang mendasarkan pandangannya sebagai seorang ahli sejarah menyarankan dalam karangannya bahwa masyarakat modern ditandai oleh bertumbuhnya ilmu penegetahuan baru, manusia yang memiliki kemampuan semakin meningkat dalam memahami rahasia-rahasia alam dan dapat menerapkan pengetahuan ini dalam berbagai kegiatan manusia. Masyarakat modern sesungguhnya merupakan hasil korelasi antara tingginya nilai peradaban manusia sebagai anggota masyarakat dengan majunya tingkat rasionalitas dalam mengkaji hasil kebudayaan. Dengan demikian memungkinkan terciptanya kehidupan masyarakat yang mantap, sejahtera, adil, makmur dan merata. ${ }^{14}$

${ }^{14}$ Abdulsyani, Sosiologi: Skematika, Teori Dan Terapan (Jakarta: Bumi Aksara, 2012), 175-176. 


\section{EKSISTENSI SURAU BUYA LUBUAK LANDUA PADA MASA KEPEMIMPINAN SYEKH MUHAMMAD BASYIR}

Surau Buya Lubuak Landua merupakan lembaga pendidikan bercorak pendidikan Islam tradisional yang dibangun pada tahun 1852 oleh Syekh Muhammad Basyir. Kemampuan Syekh Muhammad Basyir dalam mempelajari Tarekat Naqsyabandiyah menjadikan Surau Buya Lubuak Landua menjadi pusat sentral dalam mempelajari Tarekat Naqsyabandiyah pada masa itu. Di samping sebagai tempat untuk mempelajari ilmu Tarekat, Surau Buya Lubuak Landua juga memainkan peranan penting dalam penyebaran agama Islam di Pasaman Barat.

Sistem kepemimpinan pada Surau Buya Lubuak Landua diturunkan dari generasi ke generasi. Sebelum Syekh Muhammad Basyir meninggal dunia, beliau menginginkan perlu ada yang melanjutkan perjuanggannya dalam memimpin surau. Karena hal inilah Surau Buya Lubuak landau masih bertahan hingga dengan sekarang. Berikut adalah gambaran umum tentang generasi kepemimpinan Surau Buya Lubuak Landua.

1. Syekh Muhammad Basyir (wafat pada tahun 1922/Buya Lubuak Landua I).

2. Syekh Muhammad Amin (wafat pada tahun 1927/ Buya Lubuak Landua II).

3. Syekh Abdul Majid (wafat pada tahun 1984/ Buya Lubuak Landua III).

4. Syekh Abdul Jabar (wafat pada tahun 1991/ Buya Lubuak Landua IV).

5. Syekh Bahri (Buya Lubuak Landua V)

6. Syekh Mustafa Kamal (wafat pada tahun 2020/ Buya Lubuak Landua VI)

Di antara peran yang dimainkan Surau Buya Lubuak Landua:

\section{Sebagai Lembaga Pendidikan Islam Tradisional}

Selain dijadikan sebagai tempat pelaksanaan Shalat lima waktu, surau difungsikan juga sebagai tempat pendidikan Islam pada masa itu. Sistem pendidikan yang dikembangkan di Surau Buya Lubuak Landua sangatlah sederhana yaitu sistem halaqah. Dalam sistem halaqah para murid bersila dan mengelilingi dan mendengarkan pelajaran yang disampaikan oleh gurunya dan metode yang digunakan adalah berupa ceramah, pembacaan, dan hafalan. ${ }^{15}$

\section{Sebagai Lembaga Pendidikan Bela Diri Pertama di Pasaman Barat}

Kemampuan ilmu bela diri yang dimiliki Syekh Muhammad Basyir diperoleh dari kakeknya Peto Sulaiman. Oleh Peto Sulaiman Sejak kecil Syekh Muhammad Basyir telah diajarkan ilmu bela diri, ilmu ini pula lah yang kemudian diajarkan beliau kepada murid-muridnya. Syekh Muhammad Basyir mengatakan bahwa bela diri tidak hanya sebatas olahraga untuk menjaga pertahanan diri. Bela diri juga mengandung makna pengajaran bagaimana cara mengontrol emosi. Artinya orang-orang yang ahli bela diri adalah orang-orang yang telah taat dalam pelaksanaan Shalatnya serta memiliki pemahaman agama yang mempuni. ${ }^{16}$

\section{Surau Buya Lubuak Landua Merupakan Bukti Historis Pendidikan Ala Sufi}

Sebagai lembaga transmisi keilmuan Islam di Pasaman Barat pada abad-abad yang lalu, Surau Buya Lubuak Landua menyimpan khazanah naskah yang mempunyai karakter yang khas. Surau Buya Lubuak Landua dulunya menyimpan banyak koleksi naskah keagamaan, berdasarkan fakta bahwa dulunya Surau Buya Lubuak Landua merupakan tempat yang begitu masyhur di kalangan penuntut ilmu. Naskah-naskah Lubuak Landua ini memiliki karakteristik yang cukup khas, yaitu naskah-naskah lokal kontens yang ditulis oleh beberapa ulama Pasaman yang pernah menimba ilmu di tanah suci. Mei 2019.

15Tori Mardianto, (Kepala Jorong), Wawancara, 21

${ }^{16}$ Yulisman, (Penjaga Surau), Wawancara, 29 Desember 2018. 
Naskah-naskah Lubuak Landua termasuk kaya, sebab naskah-naskah ini mencakup berbagai bidang keilmuan Islam, seperti ilmu alat (Nahwu dan Sharaf), Tauhid, Fiqih dan Tasawuf. Naskahnaskah itu di dominasi oleh teks-teks Tasawuf, termasuk di dalamnya Tarikat Naqsyabandiyah, Tarikat Qadiriah, Tarikat Rifa'iyah dan Tarikat Samaniah. ${ }^{17}$ Melihat dari adanya penemuan naskah ini, surau Buya Lubuak Landua merupakan media pendidikan yang mengajarkan ilmu Tasawuf dan ini terus berkembang sampai dengan sekarang.

\section{Sebagai Tempat Pelaksanaan Suluk}

Suluk merupakan suatu ibadah yaitu melakukan perjalanan menuju kepada Allah SWT. Suluk juga disebut dengan khalwat. Khalwat artinya berdiam diri di tempat yang sunyi dan sepi agar dapat beribadah dan mengingat Allah dengan khusuk dan sempurna. Menurut Syekh Mustafa Kamal (Buya Lubuak Landua ke VI) kegiatan suluk di surau Buya Lubuak Landua berpedoman dan didasarkan kepada kisah nabi Muhammad yang berdiam diri atau berkhalwat di gua Hira.

Ketika itu Nabi Muhammad merasa sedih melihat keadaan umat yang Jahiliyah. Sementara itu nabi Muhammad tidak bisa berbuat apa-apa, karna itulah nabi mengasingkan diri ke gua Hira guna memohon dan meminta petunjuk kepada Allah atas masalah yang sedang beliau hadapi. ${ }^{18}$

Waktu pelaksanaan suluk di Surau Buya Lubuak Landua hampir sama dengan pelaksanaan suluk di tempat lain pada umumnya. Yaitu, dilaksanakan pada setiap bulan Ramadhan, yakni mulai dari sepuluh hari Sya'ban sampai hari raya Idul Fitri. Selain di waktu-waktu tersebut, suluk di Surau Buya Lubuak Landua juga biasa dilakukan pada hari-hari sebelum hari raya Idul $A d h a{ }^{19}$

Pelaksanaan suluk di Surau Buya Lubuak Landua ini dilakukan dengan cara mengurung diri

\footnotetext{
${ }^{17}$ Skerenyiki, "Surau Lubuak Landua."

${ }^{18}$ Mustafa Kamal, (Regenerasi Buya Lubuak Landua ke VI), Wawancara, 24 April 2018.

${ }^{19}$ Yarmuna, (Jamaah Surau), Wawancara, 24 April 2018.
}

disebuah tempat khusus yang terbuat dari kayu disekelilingnya ditutupi dengan kain panjang. Tempat ini sengaja dibuat khusus untuk orang yang akan melaksanakan suluk saja dengan ukuran untuk satu orang. Setiap anggota suluk memiliki satu tempatnya masing-masing. Anggota suluk hanya bisa duduk di dalamnya, dengan keadaan yang gelap, tidak terdapat apapun disana, kecuali buku doa, Al'quran dan Tasbih.

Sebelum melaksanakan suluk, biasanya para jamaah suluk akan dimandikan terlebih dahulu, dilanjutkan dengan berwudhu dan ditutup dengan membaca niat pelaksanaan suluk secara bersama, tentunya dibawah bimbingan dan pengawasan Buya Lubuak Landua. Setelah itu barulah jamaah suluk masuk ke dalam tendanya masing-masing. Mereka akan keluar dari tendanya sesuai dengan waktu yang telah ditentukan yaitu ketika telah datang waktu Shalat dan waktu makan. ${ }^{20}$

\section{EKSISTENSI SURAU BUYA LUBUAK LANDUA DI ERA MODERN}

Modernisasi merupakan suatu fenomena yang memiliki dampak dimana setiap kehidupan akan mengalami perubahan, baik perubahan itu bersifat cepat maupun lambat. Perubahanperubahan ini di dominasi oleh perkembangan teknologi yang semakin canggih. Perubahan dan modernisasi bagi surau sendiri memiliki dua dampak, yaitu dampak positif dan dampak negatif.

Surau Buya Lubuak Landua tidak dapat menghindari modernisasi. Keberadaan Surau Buya Lubuak Landua ditengah-tengah masyarakat yang sedang mengalami perkembangan akibat modernisasi menjadi tantangan tersendiri. Masuknya modernisasi ke daerah Lubuak Landua tidak terlepas dari pengaruh masyarakatnya. Adanya sikap terbuka dari masyarakat memudahkan modernisasi berkembang di daerah Lubuak Landua.

${ }^{20}$ Mustafa Kamal, (Regenerasi Buya Lubuak Landua ke VI), Wawancara, 14 Mei 2019. 
Berikut merupakan faktor masuknya modernisasi ke daerah Lubuak Landua. Pertama, Masyarakat Lubuak Landua menerima perubahan, baik perubahan dalam bidang pendidikan, ekonomi, teknologi dan lain sebagainya. Kedua, adanya penemuan baru dibidang teknologi seperti handphone dan juga televisi. Ketiga, Semakin bertambahnya jumlah penduduk Lubuak Landua. Pertambahan penduduk disebabkan oleh tingkat kelahiran yang meningkat serta adanya migrasi penduduk.

Faktor-faktor inilah yang menyebabkan Surau Buya Lubuak Landua bersinggungan langsung dengan modernisasi. Ada dua hal yang akan terjadi jika suatu kebudayaan bersinggungan dengan kebudayaan baru.

Pertama, budaya lama digantikan dengan budaya baru. Nilai-nilai tradisional lama akan hilang karena bercampurnya kebudayaan lama dengan kebudayaan baru sehingga budaya lama lambat laut akan hilang dan digantikan oleh kebudayaan baru.

Kedua, budaya lama bercampur dengan budaya baru. Maksudnya adalah budaya baru diterima, tapi nilai-nilai budaya lama tetap dipertahankan sehingga yang terjadi adalah perpaduan kebudayaan.

Dilihat dari penjelasan diatas, Surau Buya Lubuak Landua lebih mengarah kepada bentuk yang kedua yaitu Surau Buya Lubuak Landua dapat menerima perubahan, akan tetapi perubahan itu tidak menghilangkan nilai tradisonal lama yang ada pada surau.

Berikut adalah perbandingan keadaan Surau Buya Lubuak Landua sebelum masuknya modernisasi dan setelah masuknya modernisasi:

Tabel 1. Keadaan Surau Buya Landua Sebelum dan Sesudah Modernisasi

$\begin{array}{ccc}\text { No } & \begin{array}{c}\text { Sebelum masuknya } \\ \text { Modernisasi }\end{array} & \begin{array}{c}\text { Setelah masuknya } \\ \text { Modernisasi }\end{array}\end{array}$

\begin{tabular}{|c|c|c|}
\hline 1. & $\begin{array}{l}\text { Penerangan di Surau } \\
\text { Buya Lubuak Landua } \\
\text { masih menggunakan } \\
\text { alat penerangan } \\
\text { sederhana berupa } \\
\text { Lampu trongkeng } \\
\text { Dan lampu dinding. }\end{array}$ & $\begin{array}{l}\text { Setelah terjadi } \\
\text { modernisasi, alat bantu } \\
\text { penerangan yang } \\
\text { dulunya berupa lampu } \\
\text { trongkeng dan lampu } \\
\text { dinding kini berganti } \\
\text { menjadi listrik. }\end{array}$ \\
\hline 2. & $\begin{array}{l}\text { Surau Buya Lubuak } \\
\text { Landua tidak memiliki } \\
\text { alat pengeras suara. }\end{array}$ & $\begin{array}{l}\text { Sekarang } \\
\text { terdapat alat } \\
\text { bantu pengeras } \\
\text { suara berupa } \\
\text { mikrofon }\end{array}$ \\
\hline 3. & $\begin{array}{l}\text { Sistem pendidikan } \\
\text { Islam pada masa dulu } \\
\text { diajarkan } \\
\text { Oleh Syekh } \\
\text { Muhammad Basyir } \\
\text { secara langsung. }\end{array}$ & $\begin{array}{l}\text { Selain mengajarkan } \\
\text { pendidikan Islam secara } \\
\text { langsung Buya Lubuak } \\
\text { Landua juga membuka } \\
\text { sistem pengobatan gratis } \\
\text { bagi pengunjung Yang } \\
\text { ingin berobat, kemudian } \\
\text { pengunjung juga } \\
\text { diperbolehkan } \\
\text { berkonsultasi } \\
\text { dengan Buya tentang } \\
\text { masalah yang sedang } \\
\text { dialami. Misalnya: } \\
\text { konsultasi tentang } \\
\text { penyakit yang } \\
\text { di derita. }\end{array}$ \\
\hline 4. & $\begin{array}{l}\text { Surau Lubuak Landua } \\
\text { menjadi satu- satunya } \\
\text { tempat pendidikan } \\
\text { Islam pada masa itu. }\end{array}$ & $\begin{array}{l}\text { Surau Buya Lubuak } \\
\text { Landua masih dijadikan } \\
\text { sebagai tempat } \\
\text { pendidikan Islam sampai } \\
\text { dengan sekarang, } \\
\text { namun tidak } \\
\text { Menjadi tempat } \\
\text { pendidikan Islam satu- } \\
\text { satunya karena } \\
\text { dibangunnya media } \\
\text { pendidikan } \\
\text { Baru berupa } \\
\text { Sekolah oleh pemerintah } \\
\text { daerah } \\
\text { setempat. }\end{array}$ \\
\hline
\end{tabular}




\begin{tabular}{|c|c|c|}
\hline & $\begin{array}{l}\text { Jamaah atau } \\
\text { pengikut Surau Buya } \\
\text { Lubuak Landua } \\
\text { mendapatkan ilmu } \\
\text { agama dan } \\
\text { pendidikan hanya } \\
\text { dari Buya Lubuak } \\
\text { Landua saja. }\end{array}$ & $\begin{array}{l}\text { Selain } \\
\text { memperoleh ilmu agama } \\
\text { dari Buya, pendidikan } \\
\text { agama juga bisa } \\
\text { diperoleh oleh jamaah } \\
\text { dari bantuan teknologi } \\
\text { seperti hp } \\
\text { Modernisasi } \\
\text { memungkinkan jamaah } \\
\text { untuk mendapatkan } \\
\text { informasi yang kurang } \\
\text { difahami dengan } \\
\text { membrosing nya di } \\
\text { internet. }\end{array}$ \\
\hline 6. & $\begin{array}{l}\text { Dulu Buya } \\
\text { Lubuak Landua hanya } \\
\text { terfokus pada surau. }\end{array}$ & $\begin{array}{l}\text { Selain } \\
\text { Mengurus surau, } \\
\text { sekarang } \\
\text { Buya Lubuak Landua } \\
\text { Juga memiliki pekerjaan } \\
\text { lain yaitu menjadi } \\
\text { pengurus sekaligus } \\
\text { menjadi guru di } \\
\text { pesantren yang di kelola. } \\
\text { Lokasi } \\
\text { pesantren Buya Lubuak } \\
\text { Landua berada di daerah } \\
\text { Kapar, Simpang } \\
\text { Ampek } \\
\text { Kabuparen } \\
\text { PasamanBarat. }\end{array}$ \\
\hline 7 & $\begin{array}{l}\text { Pendidikan } \\
\text { yang diberikan } \\
\text { oleh Buya merupakan } \\
\text { ilmu asli yang beliau } \\
\text { dapatkan dari ulama- } \\
\text { ulama yang terkenal } \\
\text { pada masa itu }\end{array}$ & $\begin{array}{l}\text { Selain belajar } \\
\text { dari ulama, Buya Lubuak } \\
\text { Landua juga } \\
\text { memanfaatkan bantuan } \\
\text { teknologi } \\
\text { berupa handphone } \\
\text { untuk memperoleh } \\
\text { informasi mengenai } \\
\text { pendidikan Islam, } \\
\text { disamping juga sebagai } \\
\text { alat bantu komunikasi } \\
\text { bagi Buya. }\end{array}$ \\
\hline 8 & $\begin{array}{l}\text { Tidak ada kendaraan } \\
\text { pada masa dulu. } \\
\text { Semua kegiatan yang } \\
\text { dilakukan } \\
\text { oleh Buya dilakukan } \\
\text { dengan berjalan kaki. }\end{array}$ & $\begin{array}{l}\text { Buya memiliki kendaraan } \\
\text { pribadi berupa mobil. } \\
\text { Untuk memudahkan } \\
\text { Buya dalam perjalan. }\end{array}$ \\
\hline
\end{tabular}

Syekh Mustafa Kamal menuturkan bahwa Surau Buya Lubuak Landua pernah mengalami masa krisis. Krisis ini terjadi ketika adanya perubahan yang dibawa oleh colonial Belanda ke daerah Minangkabau, tak terkecali daerah Pasaman Barat. Ketika itu, surau berada dalam kepemimpinan Buya Lubuak Landua Pertama yaitu Syekh Muhammad Basyir. Situasi ini bermula ketika Pertama, masuknya tekanan ekonomi dan politik kolonial Belanda.

Pada masa ini perubahan yang dibawa oleh colonial Belanda merambah ke segala bidang tak terkecuali bidang ekonomi. Salah satu contohnya adalah Belanda memperkenalkan sistem pajak. Adanya pemberlakuan pajak pada masa itu membuat masyarakat Pasaman Barat mengalami kesulitan, masyarakat harus lebih ekstra dalam mencari nafkah dan mengumpulkan uang untuk membayar pajak. Karna keadaan inilah Surau Buya Lubuak Landua sempat mengalami krisis.

Kedua, adanya ide-ide pembaharuan keagamaan. Perubahan yang dibawa oleh kolonial Belanda juga membawa dampak perubahan di bidang keagamaan. Ide-ide pembaharuan keagamaan ini adalah adanya pembelajaran ilmuilmu baru. Pembelajaran tidak lagi terfokus kepada keagamaan saja, tetapi juga ilmu-ilmu baru seperti ilmu perhitungan, astronomi dan sebagainya.

Ketiga, pembangunan sarana pendidikan berupa sekolah. Meskipun pada masa itu sekolahsekolah yang didirikan oleh kolonial Belanda hanya di khususkan untuk anak-anak yang memiliki latar belakang dari keluarga yang kaya. Hal ini menyebabkan Surau Buya Lubuak Landua kehilangan murid karena sebagian orang tua lebih meilih sekolah karena sistem pembelajarannya lebih teratur dibandingkan dengan menuntut ilmu di surau.

Usaha dalam mempertahankan eksistensi Surau Buya Lubuak Landua tidak terlepas dari sikap sabar dan tawakkal Syekh Muhammad Basyir. Orang yang senantiasa bertawakkal kepada 
Allah akan dipermudahkan jalannya, sesuai dengan Dengan firman Allah dalam Qur'an surah AlMaidah ayat: 11 yang berbunyi: "Hai orang-orang yang beriman, ingatlah kamu akan nikmat Allah (yang diberikan-Nya) kepadamu, di waktu suatu kaum bermaksud hendak menggerakekan tangannya kepadamu (untuk berbuat jahat), maka Allab menahan tangan mereka dari kamu. Dan bertakwalah kepada Allah, dan hanya kepada Allah sajalah orang-orang mukmin itu harus bertawakekal”. (QS. Al-Midah ayat 11).

Kandungan dari ayat di atas menjelaskan bahwa sikap tawakkal kepada Allah yang ada dalam hati orang-orang yang beriman adalah salah satu sebab Allah menahan tangan orang-orang kafir yang hendak mencelakakan orang-orang yang beriman, Allah menggagalkan apa yang di ingini oleh orang-orang kafir terhadap orang-orang beriman. Dengan kata lain apapun situasi yang tengah dihadapi kendaklah kembalikan ia kepada Allah karena Allah adalah yang mengetahui segala sesuatu.

\section{DAYA TAHAN SURAU BUYA LUBUAK LANDUA}

Dalam mempertahankan eksistensi Surau Buya Lubuak Landua selain sikap tawakkal, ada beberapa upaya lain yang dilakukan Regenerasi Buya Lubuak Landua, Selain Buya Lubuak Landua pemerintah juga memiliki peran penting dalam mempertahankan eksistensi Surau Buya Lubuak Landua.

1. Upaya Regenerasi Buya Lubuak Landua dalam mempertahankan Surau Buya Lubuak Landua:

a) Menjaga unsur-unsur surau.

Lembaga pendidikan Islam tradisional akan terus diuji seiring perkembangan zaman hingga muncul kategorisasi dalam lembaga pendidikan Islam. Kemudian, karena tuntunan perubahan sistem pendidikan Islam tersebut ada beberapa unsur surau yang harus di pertahankan yaitu:

-Buya

Sebelum wafat Syekh Muhammad Basyir pernah mengatakan kepada murid-murid beliau tentang masa depan Surau Buya Lubuak Landua. Meskipun suatu saat beliau telah wafat hendaknya sistem kepemimpinan Surau Buya tetap berlanjut. Dari sinilah munculnya sejarah Regenerasi Buya Lubuak Landua. Mereka berusaha mempertahankan generasinya untuk tetap menjaga keberlangsungan surau Buya Lubuak Landua. Sebelum wafat, Syekh Muhammad Basyir telah memberikan amanah kepemimpinan surau kepada putra beliau Syekh Muhammad Amin. Kemudian beralih lagi kepada generasi berikutnya. -Jamaah

Jamaah merupakan unsur yang penting sekali dalam perkembangan sebuah surau karna langkah pertama dalam tahap-tahap mempertahankan sebuah surau adalah ada kelompok jamaah yang datang untuk belajar. Jamaah adalah sekelompok orang yang tidak bisa dipisahkan dari kehidupan surau Meskipun berdampingan dengan sarana pendidikan lain seperti sekolah, Surau Buya Lubuak Landua tetap memiliki pengikut setia.

Jamaah Surau Buya Lubuak Landua datang dari berbagai macam daerah di PasamanBarat seperti daerah Kinali, Ujung Gading, Talu, Batang Saman, dan lain-lain. Bahkan akhir-akhir ini jamaah Surau Buya Lubuak Landua ada juga yang berasal dari luar Pasaman Barat seperti berasal dari daerah Tapanuli Selatan, Pariaman, Maninjau, dan lain sebagainya.

-Kitab-kitab Islam klasik

Kitab-kitab Islam klasik seperti naskah yang disimpan oleh Regenerasi Buya Lubuak Landua memiliki karakteristik yang cukup khas, yaitu naskah-naskah lokal kontens yang ditulis oleh beberapa ulama Pasaman yang pernah menimba ilmu di tanah suci.

-Masyarakat

Selain Regenerasi Buya Lubuak Landua, masyarakat yang tinggal di daerah Surau Buya Lubuak Landua juga memiliki peran penting dalam menjaga dan melestarikan surau Buya Lubuak Landua. Buktinya fasilitas, sarana dan prasarana di Surau Buya Lubuak Landua masih 
terjaga keasliannya sejak dulu sampai dengan sekarang.

b) Menerima siapa saja yang ingin berkunjung ke Surau Buya Lubuak Landua.

c) Menerima jamaah yang datang dari berbagai macam daerah.

d) Regenerasi Buya Lubuak Landua dan pengurus Surau Buya Lubuak Landua akan menjelaskan sejarah Surau Buya Lubuak Landua kepada siapa saja yang ingin mengetahui sejarah Surau Buya Lubuak Landua.

e) Bagi masyarakat atau pengunjung yang baru pertama kali datang ke Surau Buya Lubuak Landua, pengurus Surau Buya Lubuak Landua akan menjelaskan segala yang berkaitan dengan Surau Buya Lubuak Landua, misalnya, membantu dalam menunjukkan tempat makam Regenerasi Buya, nama-nama Buya dan lain sebagainya.

2. Upaya yang dilakukan masyarakat dan pemerintah Lubuak Landua dalam mempertahankan eksistensi Surau Buya Lubuak Landua.

a) Pelaksanaan Tradisi Manjalang Buya

Untuk mengenang jasa para leluhur Buya Lubuak Landua masyarakat dan pemerintah Simpang Ampek bekerja sama dalam membuat suatu momentum yang diberi istilah "Manjalang Buya Lubuak Landua" di Nagari Persiapan Lubuak Landua Aur Kuning, Kabupaten Pasaman. Kegiatan ini berupa kegiatan yang mengenalkan wisata budaya Lubuak Landua. Acara ini biasanya diadakan pada hari keenam setelah lebaran.

Momentum ini dilakukan setiap tahunnya dalam rangka menghormati Syekh Muhammad Basyir atau yang lebih dikenal dengan Buya Lubuak Landua, karna jasa beliau menjadikan Jorong Lubuak Landua sebagai salah satu pusat pengembangan agama Islam di Pasaman Barat. Acara tradisi Manjalang Buya Lubuak Landua biasanya dihadiri oleh Bupati Kabupaten Pasaman Barat H. Baharuddin, jajaran Satuan
Kerja Perangkat Daerah (SKPD), jajaran Ninik Mamak Nan 16, dan Bundo Kanduang se-Aua Kuniang, tokoh agama Lubuak Landua, Kepala Jorong Lubuak Landua, Kapolres Pasaman Barat, Camat Pasaman, Wali Nagari setempat, serta ribuan lebih warga dan jamaah surau Buya Lubuak Landua.

Di dalam surau, di tengah hamparan, duduklah para jamaah, terlihat belasan jamba yang sengaja disiapkan oleh jajaran Ninik Mamak nan16 untuk penghormatan kepada Almarhum Syekh Muhammad Basyir. H. Burhanuddin selaku bupati Pasaman Barat menyampaikan turut merasa bangga sekaligus terharu melihat kekompakan dan keharmonisan hubungan antara cucu kemenakan Ninik Mamak Lubuak Landua Buktinya hingga saat ini tradisi yang berlandaskan Adat Basandi Syarak, Syarak Basandi Kitabullah di Lubuak Landua Masih terjaga kearifan lokalnya dengan baik. ${ }^{21}$

b) Pelaksanaan Tradisi Aia Kubah PadaMasyarakat Lubuak Landua.

Tradisi Aia Kubah merupakan tradisi yang ada pada masyarakat di Lubuak Landua. Pelaksanaaan tradisi Ziarah kubur ini lebih dikenal dengan istilah Aia Kubah. Tradisi ini dilakukan untuk menghormati orang-orang yang telah meninggal dunia, namun pelaksanaannya di makam-makam Syekh Buya Lubuak Landua. Makam Regenerasi Buya Lubuak Landua juga digunakan oleh masyarakat setempat ataupun masyarakat pendatang untuk ritual mengkabulkan hajat.

Kemampuan Surau Buya Lubuak Landua dalam memelihara unsur-unsur surau agar berfungsi dengan baik dan berkaitan antara satu sama lain menjadi alasan kuat kenapa surau lubuak landau tetap eksis sampai dengan sekarang. Landua."
${ }^{21}$ Indosiana, "Tradisi Manjalang BuyaLubuak 


\section{FUNGSI SURAU BUYA LUBUAK LANDUA}

Fungsi Surau Buya Lubuak Landua secara umum terdiri dari fungsi keagamaan, fungsi sosial, fungsi pendidikan. Berikut adalah penjelasannya:

1. Fungsi Keagamaan

a. Fungsi Zikir

Surau Buya Lubuak Landua dijadikan sebagai tempat berzikir untuk menyucikan hati, menentramkan jiwa, dan mengkhusukkan kalbu, sehingga seseorang bisa bersikap santun dan rendah hati.

b. Fungsi Pikir

Ali Bin Abi Thalib pernah berkata "tidak ada yang lebih berharga daripada sebuah kemerdekaan, dan tidak ada yang lebih mulia dari pada selesai menunaikan kewajiban." Ungkapan ini memotivasi umat Islam untuk melepaskan belenggu yang memasung kemerdekaan berfikir, berbicara dan bertindak. Tentunya dengan mengaktifkan forum Islamiah berupa surau. Surau dijadikan sebagai tempat untuk menyelesaikan permasalahan dengan jalan musyawarah serta mufakad bersama.

2. Fungsi Sosial

\section{a. Tempat Tinggal dan Singgah}

Surau dijadikansebagai tempat singgah bagi orang-orang yang sedang dalam perjalanan jauh, sebagai tempat tinggal bagi orang-orang yang kurang mampu, serta tempat tinggal bagi orang-orang yang tidak memiliki tempat tinggal.

\section{b. Tempat Pengobatan Warga}

Buya Lubuak Landua dianggap memiliki keahlian yang tidak semua orang bisa memilikinya, banyak warga yang sengaja datang ke Surau Buya Lubuak Landua untuk bertanya dan berkonsultasi tentang masalah penyakit yang diderita. Buya Lubuak Landua juga melakukan Ruqiyah kepada jamaah yang ingin dirinya di Ruqiyah.

c. Tempat Santunan Warga Dhuafa
Surau Buya Lubuak Landua juga memiliki kepedulian terhadap warga Dhuafa.

3. Fungsi Pendidikan

a. Mengajarkan kepada anak-anak baca tulis Al-Qur'an.

b. Mengajarkan kepada jamaah tentang tata cara pelaksanaan suluk.

c. Mengajaran kepada anak-anak tentang ilmu bela diri.

Selain fungsi-fungsi diatas, fungsi Surau Buya Lubuak Landua juga dapat bertransformasi sesuai dengan konteks modernisasi, hingga akhirnya dapat bertahan pada masa sekarang. Salah satu bentuknya adalah fungsi ekonomi.

4. Fungsi Ekonomi

Kegiatan pelaksanaan tradisi Manjalang Buya dan tradisi Aia Kubah sangat membantu perekonomian masyarakat Lubuak Landua. Dengan adanya tradisi ini banyak peziarah yang datang setiap waktu. Kondisi ini dimanfaatkan oleh sebagian masyarakat Lubuak Landua untuk membuka usaha kecil-kecilan seperti berdagang, membuka warung, dan juga rumah makan. Dengan demikian pendapatan masyarakat Lubuak Landua sedikit banyaknya dapat terbantu. Dengan kata lain, institusi Surau Buya Lubuak Landua dapat membantu menggerakkan potensi ekonomi masyarakat Lubuak Landua.

\section{PENUTUP}

Eksistensi Surau Buya Lubuak Landua mengalami perkembangan yang sangat signifikan. Usianya diperkirakan setua usia Islam diwilayah Pasaman Barat. Dalam perkembangannya, surau lebih terfokus pada pengajaran pendidikan agama.

Perkembangan dan daya tahan Surau Buya Lubuak Landua sebagai lembaga pendidikan Islam dapat dilakukan dengan menjalin kerjasama yang komprehensif, serta membangun komunikasi yang intensif antara pemerintah, pemuka adat, Buya, dan masyarakat. Menjadikan surau sebagai lembaga pendidikan adat dan budaya dengan mengefektifkan fungsional-fungsional yang ada di 
surau. Keberhasilan dalam mengefektifkan fungsional-funsional yang ada di Surau Buya Lubuak Landua dapat membatu menggerakkan potensi ekonomi masyarakat Lubuak Landua.

Pengembangan yang dilakukan Surau Lubuak Landua seharusnya tidak mengubah ciri khas dari surau. Bagi penguasa adat diharapkan ikut bekerja sama, serta terlibat dalam menjaga kelangsungan surau. Kepada Buya dan orangorang yang telah melibatkan diri dalam menjaga eksistensi surau diharapkan dapat membuka diri terhadap perubahan dan perkembangan kearah yang positif bagi perbaikan lembaga pendidikan surau hendaknya dapat diterima dengan baik.

Di samping itu kepada masyarakat hendaknya dapat memberikan dukungan secara materil maupun immaterial terhadap kegiatankegiatan yang dijalankan di surau. Masyarakat juga diharapkan mampu mendorong anak-anaknya untuk belajar di surau, di samping juga belajar di lembaga pendidikan modern (formal). Selanjutnya kepada para peneliti yang ingin meneliti mengenai eksistensi surau, diharapkan dapat mengembangkan hasil penelitian ini dan mempertajam analisisnya dengan menggunakan pendekatan kuantitatif.

\section{DAFTAR KEPUSTAKAAN}

\section{Buku dan Jurnal}

Abdulsyani. Sosiologi: Skematika, Teori Dan Terapan. Jakarta: Bumi Aksara, 2012.

Afdayeni, Melia. "Dinamika Sistem Pendidikan Islam (Surau) Minangkabau Pradan Pasca Pemabaharuan." Jurnal Fuaduna : Jurnal Kajian Keagamaan dan Kemasyarakatan 1, no. 1 (2017): $58-69$.

Alfurqan, Alfurqan. "Evolution and Modernization of Islamic Education In Minangkabau." Afkaruna 16, no. 1 (2020). https://journal.umy.ac.id/index.php/afkaru na/article/view/7951.

Azra, Azyumardi. Surau: Pendidikan Islam
Tradisionalis Dalam Transisi Dan Modernisasi. Jakarta: Kencana, 2017.

Darwianis. "Tindak Lanjut Kebijakan Kembali Ke Nagari Dan Ke Surau Serta Dampaknya Terhadap Kehidupan Sosial Adat Keagamaan Masyarakat.” Jurnal PPKn \& Hukum 12, no. 22 (2017): 83-101.

Hanani, Silfia. Surau: Aset Lokal Yang Tercecer. Bandung: Humaniora Utama Press, 2002.

Indosiana. "Tradisi Manjalang BuyaLubuak Landua."

Mawangir, Muhammad. "Modernization Of Islamic 'Surau' Traditional Education In West Sumatera, Indonesia." Journal of Islamic Studies and Culture 3, no. 2 (2015). http:/ /jiscnet.com/vol-3-no-2-december2015-abstract-4-jisc.

Miles, Mathew B.dan Huberman, and A Michael. Anaalisis Data Kualitatif: Buku Sumber Tentang Metode-Metode Baru, Terj. Tjetjep Rohendi Robidi. Jakarta: UI-Press, n.d.

Moenada, Meimunah S. "Surau Dan Modernisasi Pendidikan Di Masa Hindia Belanda." Sosial Budaya 8, no. 1 (2011): 40-53.

Pramono, Pramono. "Surau Dan Tradisi Penaskahan Islam Di Minangkabau, Studi Atas Dinamika Tradisi Pernaskahan Di Surau-Surau Di Padang Dan Padang Pariaman." HUNAFA: Jurnal Studia Islamika 6, no. 3 (December 15, 2009): 247. http://jurnalhunafa.org/index.php/hunafa/ article/view/137.

Ratna, Nyoman Kutha. Metodologi Penelitian: Kajian Budaya Dan Ilmu Sosial Humainiora Pada Umumnya No Title. Yogyakarta: Pustaka Pelajar, 2010.

Skerenyiki. "Surau Lubuak Landua."

Suaidi, Sholeh. "Islam Dan Modernisme." Islamuna: Jurnal Studi Islam 1, no. 1 (January 4 , 2014). http://ejournal.stainpamekasan.ac.id/index. $\mathrm{php} /$ islamuna/article/view/558.

Sunarto, Kamanto. Sosiologi Perubahan Sosial. Jakarta: Rajawali Press, 2012. 
Usman, Sunyoto. Sosiologi: Sejarah, Teori Dan Metodologi. Yogyakarta: CIReD, 2004.

Zein, Mas'ud. "Sistem Pendidikan Surau: Karakteristik, Isi Dan Literatur Keagamaan." Sosial Budaya 8, no. 1 (2011): 25-39.

\section{Wawancara}

Kamal, Mustafa. (Regenerasi Buya Lubuak Landua ke VI). Wawancara. 24 April 2018.

Mardianto, Tori. (Kepala Jorong). Wawancara. 21 Mei 2019.

Yarmuna. (Jamaah Surau). Wawancara. 24 April 2018.

Yulisman. (Penjaga Surau). Wawancara. 29 Desember 2018. 